\title{
MEMBANGUN BRAND IMAGE DALAM UPAYA MENINGKATKAN DAYA SAING SEKOLAH DI SMP MUHAMMADIYAH AL-MUJAHIDIN KABUPATEN GUNUNGKIDUL
}

\author{
Wahyudi \\ Program Pasca Sarjana \\ Universitas Muhammadiyah Yogyakarta \\ E-mail: wahyudi_syakuri@yahoo.co.id
}

\begin{abstract}
Abstrak
Penelitian ini bertujuan untuk mengetahui bagaimana membangun brand image dalam meningkatkan daya saing sekolah di SMP Muhammadiyah Al-Mujahidin, serta faktor yang mendukung dan menghambat dalam membangun brand image untuk meningkatkan daya saing sekolah di SMP Muhammadiyah Al-Mujahidin. Penelitian ini merupakan penelitian studi kasus dan pendekatan kualitatif. Kemudian data yang telah terkumpul akan diadakan penganalisaan dengan pendekatan kualitatif deskriptif untuk mengetahui upaya membangun brand image dalam meningkatkan daya saing sekolah di SMP Muhammadiyah Al-Mujahidin. Hasil Penelitian dan pembahasan menunjukkan bahwa 1) Upaya yang dilakukan dalam membangun brand image di SMP Muhammadiyah Al-Mujahidin dilaksanakan dengan cara penyampaian visi dan misi yang jelas dan menciptakan citra positif sekolah. 2) Upaya yang dilakukan dalam meningkatkan daya saing sekolah di SMP Muhammadiyah Al-Mujahidin adalah dengan menciptakan brand image sekolah yang positif.3) Faktor yang menjadi mendukung dalam membangun brand image untuk meningkatkan daya saing sekolah adalah guru, hubungan yang harmonis, sarana dan prasarana yang mendukung.
\end{abstract}

Kata kunci: brand image, daya saing

\begin{abstract}
This study aims to find out how to build a brand image in improving the competitiveness of schools in Muhammadiyah Al-Mujahidin Middle School, as well as factors that support and inhibit building brand image to improve the competitiveness of schools in Muhammadiyah Al-Mujahidin Middle School. This research is a case study and qualitative approach. Then the data collected will be analyzed using a descriptive qualitative approach to determine efforts to build brand image in improving the competitiveness of schools in Muhammadiyah Al-Mujahidin Middle School. Research and discussion results show that 1) Efforts made in building a brand image in Muhammadiyah Al-Mujahidin Middle School are carried out by delivering a clear vision and mission and creating a positive image of the school. 2) Efforts made to improve the competitiveness of schools in Muhammadiyah Al-Mujahidin Middle School is to create a positive school brand image. 3) Factors that support the building of brand image to improve school competitiveness are teachers, harmonious relationships, facilities and infrastructure which supports.
\end{abstract}

keywords: brand image, competitiveness

Info Artikel

Diterima September 2019, disetujui Oktober 2019, diterbitkan Desember 2019 


\section{PENDAHULUAN}

Disadari maupun tidak, dalam dunia pendidikan yang memasuki era global ini, masyarakat mulai sadar bahwa pendidikan merupakan unsur penting dalam menetukan masa depan putra-putrinya. Sehingga mereka akan memilih lembaga pendidikan yang dianggap memiliki keunggulan dari lembaga pendidikan yang lain. Mulai dari itulah, persaingan antar lembaga pendidikan dimulai, dan ketika lembaga pendidikan tersebut tidak peka terhadap persaingan tersebut, maka ia akan jauh tertinggal dari lembaga pendidikan lain yang telah mempersiapkan diri dalam memiliki keunggulan kompetitif.

Keunggulan lembaga pendidikan dapat dibentuk melalui pencitraan. Hal ini dapat dilakukan bila sekolah memiliki akses untuk menunjukkan keunggulan yang dimilikinya sehingga dapat menarik minat masyarakat. Maka dari itu, pihak sekolah bukan hanya berpangku tangan saja ketika mempunyai keunggulan dari lembaga pendidikan lain. Sebab melalui pengenalan keunggulan yang dimililiki sekolah, lembaga tersebut akan lebih dikenal memiliki kelebihan dari lembaga pendidikan yang lain.

Persaingan yang semakin ketat antar lembaga pendidikan Islam, tentunya perlu dilakukan pendekatan strategi lain, yaitu sudah mulai harus mengedepankan aspek citra dan reputasi lembaga pendidikan Islam melalui kegiatan atau upaya-upaya yang berhubungan dengan masyarakat sekitar. Upaya yang dilakukan merupakan sebagai bentuk pelaksanaan visi dan misi sekolah sehingga menjadikannya citra positif dalam menghadapi persaingan antar lembaga pendidikan.

Daya saing sangat diperlukan oleh lembaga pendidikan untuk memenangkan persaingan yang terjadi dalam dunia pendidikan. SMP Muhammadiyah Al-Mujahidin membangun daya saing tersebut melalui program-program unggulan yang ditawarkan oleh sekolah. Daya saing SMP Muhammadiyah Al-Mujahidin dalam beberapa tahun terakhir dirasakan cukup baik, hal ini terlihat bahwa sekolah yang berusia lampu memperoleh banyak prestasi di bidang akademik maupun non-akademik sehingga hal tersebut mampu meningkatkan minat para orang tua untuk menyekolahkan putraputrinya disekolah tersebut. Prestasi-prestasi yang diperoleh oleh siswa-siswi SMP Muhammadiyah Al-Mujahidin telah mampu meyakinkan para orang tua bahwa proses pendidikan di sekolah tersebut sudah baik.

Dari latar belakang yang telah peneliti ungkapkan maka peneliti tertarik untuk melakukan penelitian dengan judul "Membangun Brand Image Dalam Upaya Meningkatkan Daya Saing Sekolah Di SMP Muhammadiyah Al-Mujahidin".

\section{METODE PENELITIAN}

Penelitian ini merupakan penelitian yang menggunakan pendekatan kualitatif, yaitu prosedur penelitian yang menghasilkan data deskriptif berupa kata-kata tertulis atau lisan dari orang atau perilaku yang dapat diamati. Bodgan dan Tylor, mengatakan bahwa "metode penelitian adalah prosedur-prosedur riset yang menghasilkan data kualitatif yang berisi ungkapan atau catatan orang itu sendiri atau tingkah laku mereka yang observasi”.

Dalam melaksanakan studi ini, peneliti ingin menjelaskan secara rinci tentang halhal yang berkaitan dengan masalah metode penelitian yang dipakai. Masalah penelitian tersebut di antaranya meliputi: pendekatan dan jenis penelitian, kehadiran penelitian, data dan sumber data penelitian, teknik pengumpulan data, teknik analisis data, pengecekan keabsahan data. 


\section{HASIL PENELITIAN DAN PEMBAHASAN}

Hasil Penelitian dan pembahasan menunjukkan bahwa 1) Upaya yang dilakukan dalam membangun brand image sekolah dilaksanakan dengan cara penyampaian visi dan misi yang jelas dan menciptakan citra positif sekolah dengan mendorong guru-guru untuk meningkatkan professionalismenya, menciptakan lingkungan yang kondusif, pembelajaran yang ramah siswa, membangun manajemen yang kuat, menciptakan kurikulum yang luas tapi seimbang, penilaian dan pelaporan prestasi siswa yang bermakna, serta pelibatan orang tua dan masyarakat. 2) Upaya yang dilakukan dalam meningkatkan daya saing sekolah adalah dengan menciptakan brand image sekolah yang positif, senantiasa mengantisipasi pesaing dan munculnya kompetitor baru, dan menciptakan program-program unggulan. 3) Faktor yang menjadi mendukung dalam membangun brand image untuk meningkatkan daya saing sekolah adalah guru, hubungan yang harmonis, sarana dan prasarana yang mendukung pembelajaran, kerjasama yang baik, kondisi lingkungan sekitar dan iklim sekolah yang kondusif dan nyaman, serta letak sekolah yang strategis. Adapun hambatan yang dihadapi adalah dibagian pendanaan dan koordinasi.

\section{SIMPULAN DAN REKOMENDASI}

Dari hasil penelitian dan pembahasan diatas, peneliti dapat menarik beberapa kesimpulan sebagaimana yang tercantum berikut ini : 1) Dalam membangun brand image sekolah dilaksanakan dengan cara penyampaian visi dan misi yang jelas dan menciptakan citra positif sekolah; 2) Dalam meningkatkan daya saing sekolah adalah menciptakan brand image sekolah yang positif, senantiasa mengantisipasi pesaing dan munculnya kompetitor baru, dan menciptakan program-program unggulan; 3) Yang mendukung dalam membangun brand image untuk meningkatkan daya saing sekolah adalah guru-guru yang kreatif dan mampu bekerjasama dengan baik, memiliki hubungan yang harmonis didalam sekolah maupun diluar sekolah dengan para stakeholder, sarana prasarana yang mendukung pembelajaran, kerjasama yang baik antara pengurus dan pihak manajemen sekolah, kondisi lingkungan sekitar dan iklim sekolah yang kondusif dan nyaman bagi pembelajaran, serta letak sekolah yang strategis. Adapun hambatan dalam membangun brand image untuk meningkatkan daya saing sekolah adalah dibagian pendanaan dan koordinasi. Dan kerjasama yang baik merupakan kunci dalam menyelesaikan setiap hambatan yang muncul.

\section{DAFTAR PUSTAKA}

Armai Arief. 2007. Reformasi Pendidikan Islam. Ciputat. Ciputat Press Group

Barnawi dan Mohammad Arifin. 2013. Branded School: Membangun Sekolah Unggul Berbasis Peningkatan Mutu. Jogjakarta. Ar-Ruzz Media.

Bodgan, Robert Dan Tylor, Steven J. 1993. Kualitatif Dasar-Dasar Penelitian, Ed, Afandi, A. Khozin. Surabaya. Usaha Nasional.

Darmiyati Zuchdi. 2008. Seri Metodologi Penelitian, Panduan Penelitian Analisis Konten. Yogyakarta. Lembaga Penelitian IKIP Yogyakarta.

Dedy Mulyasana. 2015. Pendidikan Bermutu dan Berdaya Saing. Bandung. Remaja Rosdakarya. 
Halimatus Syadiyah. 2013. Jurnal Ilmiah Kacaunya Pendidikan Di Indonesia. Jurusan Kurikulum Dan Teknologi Pendidikan. Universitas Negeri Semarang.

Hasbullah. 2006. Otonomi Pendidikan: Kebijakan Otonomi Daerah dan Implikasinya Terhadap Penyelenggaraan Pendidikan. Jakarta. Raja Grafindo Persada.

Hendrawan Prasetyo. 2014. Dampak Kebijakan Akreditasi Perguruan Tinggi Terhadap Daya Saing (Conpetitiveness) Perguruan Tinggi Swasta Di Kabupaten Kebumen. Jurnal Fokus Bisnis.

Iqbal Hasan. 2002. Pokok-Pokok Materi Metodologi Penelitian. Jakarta. Galia Indonesia.

Kotler, P., dan Keller, K.L. 2009. Manajemen Pemasaran. Jakarta. PT. Indeks.

Kunandar. 2007. Guru Profesional: Implementasi Kurikulum Tingkat Satuan Pendidikan (KTSP) dan Persiapan Menghadapi Serttifikasi. Jakarta. Raja Grafindo Persada.

Lincoln, Y.S. And. E. G. Guba. 1985. Naturalistic Inquiry. Beverly Hills. Sage Publications.

M. Djuanaidi Ghany dan Fauzan Almashur. 2013. Metode Penelitian Kualitatif Edisi Revisi. Jogjakarta. Ar-Ruzz Media.

M. Djuanidi Ghony dan Fauzan Almansur. 2012. Metode Penelitian Kualitatif. Jogjakarta.

Muhadjir, Neng. 1990. Metodologi Penelitian Kualitatif. Yogyakarta. Rake Sarasin.

Mulyasa E. 2006. Standar Kompetensi Dan Sertifikasi Guru. PT Remaja Rosdakarya.

Nasution. 1988. Metode Penelitian Naturalistik-Kualitatif. Bandung. Tarsito.

Nasution. 1990. Metode Penelitian Naturalistik-Kualitatif. Bandung, Tarsito.

Rangkuti, Freddy. Analisis Swot Teknik Membedah Kasus Bisnis.

Rosady Ruslan. 1995. Aspek-Aspek Hukum dan Etika Dalam Aktifitas Public Relations Kehumasan. Jakarta. Ghalia Indonesia.

Sugiono. 2003. Metode Penelitian Administrasi. Bandung. Alfabeta.

Sugiyono. 2009. Metode Penelitian Kuantitatif Kualitatif. Bandung. Alfabeta.

Sugiyono. 2011. Metode Penelitian Kuantitaif, Kualitatif Dan R \& D. Bandung. Alfabeta. 
Sumardi Soerybrata. 1998. Metode Penelitian. Jakarta. Raja Grafindo

Syaikhudin. 2013. Pola Kepemimpinan Kepala Sekolah Madrasah dalam Meningkatkan Mutu Pendidikan Studi. Yogyakarta. UIN Sunan Kalijaga. 